\title{
PW03-013 - Behçet's disease: genotype-phenotype correlations
}

\author{
M Takeuchi ${ }^{1,2^{*}}$, T Kawagoe $^{1}$, A Meguro $^{1}$, Y Ishigatsubo ${ }^{3}$, E Remmers $^{2}$, D Kastner $^{2}$, N Mizuki $^{1}$ \\ From 7th Congress of International Society of Systemic Auto-Inflammatory Diseases (ISSAID) \\ Lausanne, Switerland. 22-26 May 2013
}

\begin{abstract}
Introduction
Although the therapy for Behçet's disease (BD) has improved since infliximab was approved for refractory retinochoroiditis therapy in Japan, the exact pathogenesis of BD remains unclear. Our recent genome-wide association study has identified the $I L 10$ and IL23RIL12RB2 loci as susceptibility genes for $\mathrm{BD}$, in addition to $H L A-A * 26$ and $B * 51$. rs1495965 is located in the intergenic region between $I L 23 R$ and $I L 12 R B 2$ and rs1800872 is located in the promoter region of IL10. IL-10 is an anti-inflammatory cytokine that may have multiple effects in immunoregulation and inflammation. It is thought that regulatory $\mathrm{T}$ cell function related to IL-10 is an important factor in the disease pathogenesis.
\end{abstract}

\section{Objectives}

To examine the association of IL23R-IL12RB2 and IL10 gene polymorphisms and HLA typing with clinical presentation of $\mathrm{BD}$, and to examine the expression levels of IL10 mRNA, IL23R mRNA, and IL12RB2 mRNA from PBMCs from each genotype in healthy controls.

\section{Methods}

A total of 464 patients with BD enrolled in our recent genome-wide association study were investigated for association between clinical manifestations and 4 susceptibility loci, rs1495965, rs1800872, $H L A-A * 26$, and $H L A-B * 51$. In our cohort, 196 patients had complete BD and 268 patients had incomplete BD. The expression levels of IL10 mRNA, IL23R mRNA, and IL12RB2
mRNA were examined in 33 healthy controls by realtime PCR.

\section{Results}

The frequency of complete BD was significantly increased in patients with the risk allele of rs 1800872 under genotypic and recessive models $(\mathrm{p}=0.0004,0.0003$, respectively). The frequency of skin lesions, ocular lesions, and genital ulcers was also increased in patients homozygous for the risk allele of $\operatorname{rs} 1800872(\mathrm{p}=0.02$, $0.05,0.05$, respectively). $H L A-A * 26, H L A-B * 51$, and the rs1495965 risk allele showed no association with the frequencies of complete or incomplete BD or specific clinical findings. The frequency of patients with refractory chorioretinal uveitis treated with infliximab was significantly increased among the risk allele carriers of rs1495695 and rs1800872 ( $\mathrm{p}=0.01,0.02$, respectively). The expression level of IL10 mRNA was significantly decreased in the homozygotes for the rs 1800872 risk allele. There were no significant differences in the expression levels of IL23R mRNA and IL12RB2 mRNA among rs1495695 risk allele carriers.

\section{Conclusion}

This study suggests that the IL10 polymorphism associates with complete BD and the IL23R-IL12RB2 and IL10 gene polymorphisms associate with the severity of uveitis. The latter association may be due to regulation of IL10 mRNA expression.

\section{Disclosure of interest}

None declared. 


\section{Authors' details}

'Department of Ophthalmology, Yokohama City University, Yokohama, Japan. ${ }^{2}$ Inflammatory Disease Section, Medical Genetics Branch, National Human Genome Research Institute, National Institute of Health, Bethesda, USA. ${ }^{3}$ Department of Internal Medicine and Clinical Immunology, Yokohama City University, Yokohama, Japan.

Published: 8 November 2013

doi:10.1186/1546-0096-11-S1-A239

Cite this article as: Takeuchi et al.: PW03-013 - Behçet's disease

genotype-phenotype correlations. Pediatric Rheumatology 2013 11(Suppl 1):

A239.

Submit your next manuscript to BioMed Central and take full advantage of:

- Convenient online submission

- Thorough peer review

- No space constraints or color figure charges

- Immediate publication on acceptance

- Inclusion in PubMed, CAS, Scopus and Google Scholar

- Research which is freely available for redistribution

Submit your manuscript at www.biomedcentral.com/submit

Ciomed Central 